\title{
Evaluation of Different Organic Fertilizers in the Sustainable Cultive of Coriander
}

\author{
Rafael Santiago da Costa $^{1}$, Letícia Kenia Bessa de Oliveira ${ }^{1}$, José Lucas Guedes dos Santos ${ }^{2}$, \\ Aiala Vieira Amorim², Jorge Cá ${ }^{2}$, Maria Clarete Cardoso Ribeiro², Rosilene Oliveira Mesquita ${ }^{1}$ \\ $\&$ Marilena de Melo Braga ${ }^{1}$ \\ ${ }^{1}$ Department of Agronomy/Plant Science, Federal University of Ceará, Fortaleza, Ceará, Brazil \\ ${ }^{2}$ Institute of Rural Development, University of International Integration of Afro-Brazilian Lusophony, Redenção, \\ Ceará, Brazil \\ Correspondence: Rafael Santiago da Costa, Department of Agronomy/Plant Science, Federal University of Ceará, \\ Fortaleza, Ceará, Brazil. Tel: 85-992-593-389. E-mail: rafaelsantiagodacosta@yahoo.com.br
}

Received: January 27, 2019

Accepted: March 3, 2019 Online Published: May 15, 2019

doi:10.5539/jas.v11n6p299

URL: https://doi.org/10.5539/jas.v11n6p299

\begin{abstract}
The excessive use of agrochemicals in agriculture has been causing irreversible environmental impacts, from this point of view, organic farming appears as an economically viable alternative to minimize these impacts. So, the objective of this work was to evaluate the effect of different types organic fertilizers in the development and production of coriander harvested at different epochs. The experiment was conducted during the period from August to October 2016, in an area of the experimental farm of University of International Integration of Afro-Brazilian Lusophony. The experimental design was a randomized complete block design, in a $5 \times 4$ factorial scheme, consisting of five organic fertilizers and four harvesting epochs $(28,35,42$ and 49 days after planting-DAP) and five blocks. The variables stem diameter, plant height, root size, number of leaves, leaf length and productivity were evaluated. All the analyzed variables responded significantly by the F test, either for the qualitative factor, fertilizer sources, or the quantitative, epochs of evaluation. Regarding the cultivation epochs, when the first evaluation period (28 DAP) was compared with the last (49 DAP), it was verified that the variables presented linear responses over time, with increases of $34.4 \%$ for height, $29.5 \%$ for stem diameter, $37.07 \%$ for root length and $64.44 \%$ for production. In relation to the fertilizer sources, in general, the cattle manure provided a greater growth and production of the coriander plants, being therefore the most suitable for the cultivation.
\end{abstract}

Keywords: Coriandrum sativum, family agriculture, organic production, sustainability

\section{Introduction}

Among the major problems faced in the last decades, environmental degradation has been highlighted, potentiated by some factors, such as high demand for food, use of chemical inputs for agricultural production and land misuse (Woolpert, 2015). It is known that with the exponential increase of the population and the increasingly scarce natural resources, producers have sought new techniques and sustainable alternatives to improve agricultural production and the production system as a whole (Silva et al., 2017).

Faced with this problem, organic agriculture appears as an alternative proposal for the use of chemical inputs, which encompasses besides the benefits to the environment, local participation and the empowerment of family farmers. According to Zen and Brandão (2018), among vegetables produced by small producers, vegetables stand out, with a rapid cycle, good financial return and economic viability, but they are highly demanding with regard to nutrition.

Coriandrum sativum L., an annual herbaceous herring crop of considerable value and importance in several regions of Brazil, especially in the Northeast, where it is widely consumed (Linhares et al., 2015). The fertilization used in this crop is usually done in a random way, without any theoretical and scientific basis, which often makes the plants do not present good answers.

According to Signor and Cerri (2013), the efficient management of fertilization requires the knowledge of the nutrient mineralization dynamics, influencing the productive form, and seeking to optimize the timing of crop 
demand in relation to nutrient availability in the soil, thus avoiding immobilization or mineralization of them. The development of strategies related mainly to the use of resources derived from the agricultural property itself, allows the recycling of by-products, reducing expenses and reducing dependence on non-renewable resources (Costa et al., 2017).

In this perspective, organic matter, bovine manure and earthworm humus appear as important components in the formulation of organic fertilizers, because when mixed with the soil, they contribute with physical and chemical attributes, improving the soil structure and providing the necessary nutrients to the plant development (Costa et al., 2017; Saldaña et al., 2014). The use of these byproducts ends up reducing the cost of production of the horticulturists, providing an increase in the production of this important crop and linked to that, enable a more sustainable agricultural production.

However, despite the numerous studies in the area of organic production, there are still few that compare organic fertilizers used in the same experiment to distinguish which is the best. Many confine themselves to making comparisons with chemical fertilizers, or with other research, leaving environmental and regional factors somewhat aside. In this context, the objective of this work was to evaluate the effect of different types of organic fertilizers on the development and production of coriander harvested at different times.

\section{Material and Methods}

The experiment was conducted during the period from August to October 2016, in an area of the experimental farm of the International University of Afro-Brazilian Lusophony (UNILAB), located in the Piroás, in the municipality of Redenção, in the Maciço of Baturité, Ceará $\left(04^{\circ} 14^{\prime} 53^{\prime \prime} \mathrm{S}, 38^{\circ} 45^{\prime} 10^{\prime \prime} \mathrm{W}\right.$ and average altitude ranging from 240 to $340 \mathrm{~m}$ ). According to the classification of Köppen, the climate of the place is $A w^{\prime}$, that is, tropical rainy, very hot, with predominance of rains in the seasons of summer and autumn.

The experimental design was a randomized complete block design, in a $5 \times 4$ factorial scheme, consisting of four fertilizations + one treatment no fertilization, four harvest periods $(28,35,42$ and 49 days after planting-DAP) and five blocks. The treatments used were: $\mathrm{T} 1=$ no fertilization (reference treatment), $\mathrm{T} 2=$ bovine manure, $\mathrm{T} 3=$ earthworm humus, $\mathrm{T} 4=$ vegetal organic matter and $\mathrm{T} 5=$ bovine manure + earthworm humus + vegetal organic matter (1:1:1, v:v:v). For each treatment, the amount of $30 \mathrm{tha}^{-1}$ was used, according to the recommendations of Cavalcanti and Lima (2008).

The organic inputs were obtained from the experimental farm of UNILAB. Bovine manure (obtained still moist) was disposed in the form of a pile and placed for tanning during the period of 30 days. The pile was wetted daily and mixed every two days. The organic matter was obtained through the composting of residues from sugarcane (bagasse and leaves) and foliage of ornamental plants, following the same format used in manure, but in a period of 40 days and with the temperature being checked daily. As for worm humus, this was obtained through vegetable remains of vegetables in a period of 30 days.

After obtaining the inputs, they were duly sieved in a $2 \mathrm{~mm}$ mesh and sent for chemical analysis in the Laboratory of Chemistry and Fertility of the soil of the Federal University of Ceará (UFC), together with a soil sample (T1) where it was carried out the experiment (argisol). The results obtained are available in Table 1.

Table 1. Chemical soil attributes, in the 0 to $0.20 \mathrm{~m}$ depth layer, and of the fertilizers

\begin{tabular}{|c|c|c|c|c|c|c|c|c|c|}
\hline Treat. & C & M.O. & $\mathrm{N}$ & $\mathrm{P}$ & K & $\mathrm{Na}^{+}$ & $\mathrm{Ca}^{2+}$ & $\mathrm{Mg}^{2+}$ & CTC \\
\hline & 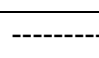 & $-\mathrm{g} \mathrm{kg}^{-1}$ & -------- & $\mathrm{mg} \mathrm{dm^{3 }}$ & cmolc $\mathrm{dm}^{3}$ & $\mathrm{mg} \mathrm{dm}{ }^{3}$ & \multicolumn{3}{|c|}{ - } \\
\hline T1 & 11.60 & 20.1 & 1.2 & 42.33 & 104 & 0.21 & 2.2 & 1.9 & 98.98 \\
\hline $\mathrm{T} 2$ & 4.87 & 8.6 & 129.2 & 74 & 364 & 115 & 9.7 & 7.4 & 135.34 \\
\hline $\mathrm{T} 3$ & 2.6 & 4.1 & 1.86 & 140 & 1646 & 459 & 2.9 & 4.3 & 166.2 \\
\hline $\mathrm{T} 4$ & 3.4 & 7.7 & 108.2 & 365 & 376 & 168 & 9.8 & 3.2 & 183.44 \\
\hline T5 & 4.92 & 8.7 & 97 & 338 & 392 & 154 & 9.5 & 7.5 & 171 \\
\hline
\end{tabular}

Note. $\mathrm{T} 1=$ no fertilization $($ reference treatment), $\mathrm{T} 2=$ bovine manure, $\mathrm{T} 3=$ earthworm humus, $\mathrm{T} 4=$ vegetal organic matter and $\mathrm{T} 5=$ bovine manure + earthworm humus + vegetal organic matter

Source: Laboratory of Chemistry and Soil Fertility of the Federal University of Ceará.

Fifteen days before planting the inputs were incorporated into the beds. Seeds of the true variety were used, distributed in five beds, each measuring $10 \mathrm{~m}$ in length, $1.20 \mathrm{~m}$ in width and $15 \mathrm{~cm}$ in height. The amount of $3 \mathrm{~g}$ 
of seeds distributed per meter of furrow was standardized and the sowing was performed manually and directly in 4 furrows spaced $20 \mathrm{~cm}$ to $1 \mathrm{~cm}$ deep. Irrigation was performed twice per day by micro-sprinkler irrigation, calculated on the basis of evapotranspiration estimated from evaporation in the Class A tank.

At the defined seasons $(28,35,42$ and 49 DAP), 50 plants were collected from the central grooves at each treatment (10 plants per block) and the following variables were verified: plant height (PH), stem diameter (SD), root length (RL), leaf length (LL), number of leaves (NL) and productivity (PROD). For these determinations a digital caliper, a scale graded in $\mathrm{cm}$ and a precision scale were used. With the postion of these data, was still calculated the plant height ratio and stem diameter (PH/SD).

The qualitative nature data of the analyzed variables, were submitted to analysis of variance and, later, when significant by the $\mathrm{F}$ test, submitted to Tukey's test at the $5 \%$ level of significance. For the data of quantitative nature conducted a regression analysis, the equations that best fit to the data, were selected based on the significance of the regression coefficients to $1 \%$ and $5 \%$ probability by the $\mathrm{F}$ test and with greater determination coefficient, or higher $\mathrm{R}^{2}$. For the statistical analysis the computational program "ASSISTAT 7.7 BETA".

\section{Results and Discussion}

Through the statistical analysis (Table 2), it was verified that all the analyzed variables responded significantly to the qualitative factor sources of fertilizer at the level of $1 \%$ of probability by the test $\mathrm{F}$. For the quantitative factor evaluation times, only the variable relationship between plant height and stem diameter (PH/SD) did not respond significantly to the $\mathrm{F}$ test and, with respect to the interaction between fertilizer sources (F) and seansons (S), it was found that only the leaf length (CF) and leaf number (NF) variables were significantly different at the $1 \%$ and $5 \%$ probability levels, respectively, by the $\mathrm{F}$ test.

Table 2. Analysis of variance for plant height (PH), stem diameter (SD), plant height ratio and stem diameter $(\mathrm{PH} / \mathrm{SD})$, root length $(\mathrm{RL})$, leaf length (LL), number of leaves $(\mathrm{NL})$ and productivity (PROD) of coriander plants cultivated under different organic fertilizer sources and evaluated at different times $(28,35,42$ and 49 DAP)

\begin{tabular}{lllllllll}
\hline \multirow{2}{*}{ Source of Variation } & \multirow{2}{*}{$\mathrm{GL}$} & \multicolumn{7}{c}{ Medium Square } \\
\cline { 3 - 8 } & & $\mathrm{PH}(\mathrm{cm})$ & $\mathrm{SD}(\mathrm{mm})$ & $\mathrm{PH} / \mathrm{SD}$ & $\mathrm{RL}(\mathrm{cm})$ & $\mathrm{LL}(\mathrm{cm})$ & $\mathrm{NL}$ & PROD $(\mathrm{kg} \mathrm{m})$ \\
\hline Fertilizers $(\mathrm{F})$ & 4 & $2147.01^{* *}$ & $12.45^{* *}$ & $96.45^{* *}$ & $333.04^{* *}$ & $32.97^{* *}$ & $444.61^{* *}$ & $3225^{* *}$ \\
Seasons (S) & 3 & $573.81^{* *}$ & $10.83^{* *}$ & $0.55^{\mathrm{ns}}$ & $99.86^{* *}$ & $28.21^{* *}$ & $512.22^{* *}$ & $6702^{* *}$ \\
Int. F $\times \mathrm{S}$ & 12 & $16.65^{\mathrm{ns}}$ & $0.17^{\mathrm{ns}}$ & $1.41^{\mathrm{ns}}$ & $5.59^{\mathrm{ns}}$ & $0.62^{* *}$ & $22.67^{*}$ & $2777^{\mathrm{ns}}$ \\
Blocks & 4 & 28.10 & 1.41 & 6.23 & 10.15 & 1.84 & 20.57 & 1137 \\
Residue & 76 & 28.93 & 0.48 & 2.12 & 4.84 & 0.22 & 10.46 & 3108 \\
\hline Average overall & - & 26.91 & 4.53 & 6.06 & 9.4 & 5.11 & 12.99 & 12.59 \\
CV $\%$ & - & 19.90 & 15.34 & 24.05 & 23.4 & 9.23 & 24.89 & 44.28 \\
\hline
\end{tabular}

Note. $\mathrm{GL}=$ Degree of freedom; $\mathrm{CV}=$ Coefficient of variation; $* *$ Significant at the $1 \%$ probability level by the $\mathrm{F}$ test; * Significant at the $5 \%$ probability level by the $\mathrm{F}$ test; $\mathrm{ns}=$ Not significant.

According to the mean comparison test (Table 3), it was verified that the highest average found for the variable height of plants was $37.38 \mathrm{~cm}$, and this value was identified when the plants were submitted to treatment with bovine manure (T2). When comparing this value with the minimum value obtained when the plants were cultivated without fertilization (T1), there was a significant reduction of $59.44 \%$ in plant height. When the fertilization was carried out with organic matter (T4), the plants presented a mean $0.8 \%$ lower than the plants fertilized with bovine manure, thus, there was no significant difference by the Tukey test at $5 \%$ probability between both the treatments. 
Table 3. Mean of plant height (PH), stem diameter (SD), plant height ratio and stem diameter ( $\mathrm{PH} / \mathrm{SD})$, root length (RL) and productivity under different sources of organic fertilizer to 49 days after planting

\begin{tabular}{llllll}
\hline Sources of Fertilizer & PH $(\mathrm{cm})$ & SD $(\mathrm{mm})$ & PH/SD & RL $(\mathrm{cm})$ & PROD $(\mathrm{kg} \mathrm{m})^{2}$ \\
\hline T1 & $15.16 \mathrm{c}$ & $4.26 \mathrm{~b}$ & $3.62 \mathrm{c}$ & $5.14 \mathrm{c}$ & $1.98 \mathrm{bc}$ \\
T2 & $37.38 \mathrm{a}$ & $5.65 \mathrm{a}$ & $6.59 \mathrm{~b}$ & $12.96 \mathrm{a}$ & $3.96 \mathrm{a}$ \\
T3 & $18.06 \mathrm{c}$ & $4.77 \mathrm{~b}$ & $3.91 \mathrm{c}$ & $5.65 \mathrm{c}$ & $2.80 \mathrm{ab}$ \\
T4 & $37.08 \mathrm{a}$ & $4.49 \mathrm{~b}$ & $8.39 \mathrm{a}$ & $14.06 \mathrm{a}$ & $3.31 \mathrm{bc}$ \\
T5 & $26.88 \mathrm{~b}$ & $3.48 \mathrm{c}$ & $7.79 \mathrm{ab}$ & $9.21 \mathrm{~b}$ & $1.72 \mathrm{c}$ \\
\hline
\end{tabular}

Note. $\mathrm{T} 1=$ no fertilization, $\mathrm{T} 2=$ bovine manure, $\mathrm{T} 3=$ earthworm humus, $\mathrm{T} 4=$ vegetable organic matter and $\mathrm{T} 5$ = bovine manure + earthworm humus + organic vegetable matter. Means followed by the same letter in the column do not differ significantly by the Tukey test at $5 \%$ probability.

Linhares et al. (2015), when evaluating the productivity of coriander fertilized with different doses of bovine manure, observed that the height of the plants was influenced significantly by the increase of the doses of the input, presenting a maximum height of $18.1 \mathrm{~cm}$ when submitted to dose of $60 \mathrm{t} \mathrm{ha}^{-1}$. The lower height found in the work of Linhares et al. (2015) compared to the data obtained in the present research, may be related to the maturation of manure used in both experiments, climatic factors and growing season. Similar results were found by Tavella et al. (2010), that when working with coriander cultivation under no-tillage system and submitted to fertilization with organic composed of bovine manure and vegetal remains, verified a higher height of plants $(30.27 \mathrm{~cm})$ when they were submitted to dose of $30 \mathrm{tha}^{-1}$.

Regarding the diameter of the stem (Table 3), it was found that the highest average was found when the plants were submitted to fertilization with bovine manure (T2), presenting a maximum value of $5.65 \mathrm{~mm}$. When comparing the maximum value with the minimum value (3.48), verified when the plants were fertilized with the mixture between cattle manure + earthworm humus + vegetal organic matter (T5), a reduction of $38.4 \%$ was observed in SD. In comparing the best fertilization for this variable (T2) and the treatment without fertilization (T1), a reduction of $24.6 \%$ was observed, showing that a quality fertilization for vegetables becomes essential for the development the same.

The positive effect of bovine manure on plant development is due not only to the supply of nutrients but also to the improvement of the physical structure of the soil and to the supply of organic molecules plant growth promoters , such as auxins (Wolka \& Melaku, 2015; Zandonadi et al., 2013). Therefore, superior stem diameter results when the plants were fertilized with bovine manure may be related to the physical and chemical improvements when it was used in the soil.

The reduction in stem diameter observed in treatment with bovine manure + earthworm humus + vegetable organic matter (T5), in turn, may be related to the physical properties of humus, which, although not used pure, may have increased retention of water in the soil and consequently decreased its aeration, according to Gonet et al. (2008), thus hindering its absorption by vegetables.

In relation to the variable relationship between plant height and stem diameter (Table 3), in turn, presented a higher mean $\left(8.39 \mathrm{~cm}^{-1} \mathrm{~mm}^{-1}\right)$, when the plants were submitted to treatment with (T4), while the lowest mean $\left(3.62 \mathrm{~cm}^{-1} \mathrm{~mm}^{-1}\right)$ was observed in the absence of fertilization (T1), thus a reduction of $56.8 \%$. When exposed to treatment with bovine manure + earthworm humus + vegetal organic matter (T5), the plants presented an average of $7.1 \%$ lower than the plants fertilized with organic matter only, and there was no significant difference between both treatments.

This relationship represents the egalitarian elevation between plant height and stem diameter, characterizing non unbalanced growth. Possibly, the vegetal organic matter propitiated a proportionality among these variables due to the slow release of the nutrients, that is directly related to the speed of mineralization of the compound. According to Zandonadi et al. (2013), besides being a source of nutrients, the organic matter presents surface loads that contribute to the increase of the cation exchange capacity (CEC) of the soil and, due to its high reactivity, regulates the availability of several nutrients, in especially the micronutrients, which can be observed in Table 1.

Results divergent to this work were observed by Rodrigues et al. (2010), who evaluated the production of tomato seedlings in substrates with different levels of organic compost and containers in protected environment, found that there was no significant effect of the substrates on the relationship between plant height and stem diameter. 
This divergence of results may be related to the phenological stage of the plants, the type of substrate used, as well as the climatic conditions of the studies.

For the root length variable (Table 3), a higher average $(14.06 \mathrm{~cm}$ ) was observed when the coriander plants were submitted to fertilization with organic vegetable matter (T4), which did not differ statistically from the treatment with bovine manure (T2), which presented a mean of $12.96 \mathrm{~cm}$. When comparing the maximum value with the minimum value $(5.14 \mathrm{~cm})$, found when the plants were under soil with no fertilization, a significant reduction of $63.4 \%$ was observed. This positive result may be related to the higher availability of nutrients in the soil at the time of higher crop requirement (Trivelin et al., 2013).

Regarding the productivity variable (Table 3), it was found that the highest average found was $3.96 \mathrm{~kg} \mathrm{~m}^{2}$, when the coriander plants were fertilized with bovine manure (T2). When comparing the maximum value of productivity with the minimum value $\left(1.72 \mathrm{~kg} \mathrm{~m}^{2}\right)$, verified in the treatment with bovine manure + earthworm humus + vegetal organic matter (T5), plants presented a significant reduction of $56.57 \%$. Oliveira et al. (2002), when working with coriander $\mathrm{cv}$. verified maximum productivity of green mass of $5.0 \mathrm{~kg} \mathrm{~m}^{2}$ obtained when the plants were fertilized with $3.9 \mathrm{~kg} \mathrm{~m}^{2}$ of bovine manure in the presence of mineral fertilizer. This superiority in the green mass productivity may be related to the presence of mineral fertilizers.

In general, treatment with bovine manure + earthworm humus + vegetable organic matter (T5) presented a greater accumulation of nutrients in relation to the other treatments (Table 1), but this treatment reduced the variables SD and productivity. These negative results may be related to the effect of the toxicity caused by the excess of some nutrients, and this was verified visually, where the plants presented marginal chlorosis of the older leaves. According to Rout and Sahoo (2015), mineral nutrients perform essential and specific functions, therefore their deficiency or toxicity is observed through symptoms, often characteristic for each nutrient, being dependent on the cultivar studied and the environmental factors.

Regarding the quantitative factor epochs, the variables plant height and stem diameter were adjusted to two increasing linear equations, with an increase of $0.53 \mathrm{~cm}$ (Figure 1A) and $0.072 \mathrm{~mm}$ (Figure 1B), respectively, along of epochs of evaluation. When comparing the minimum point (21.38 and 3.7) found in season 28 DAP with the maximum point observed in season 49 DAP (32.6 and 5.25), there was a $34.4 \%$ increase for height of plants and $29.5 \%$ for stem diameter.
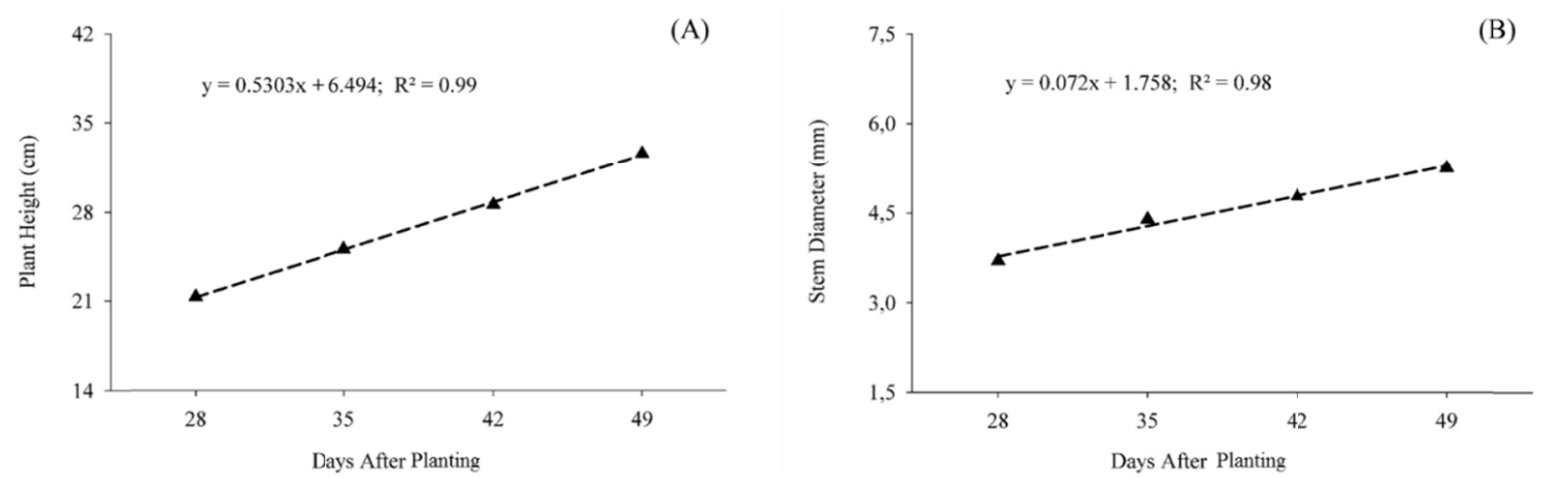

Figure 1. Plant height (A) and stem diameter (B) of coriander plants evaluated at different times after sowing Note. ${ }^{* *}$ Significance at $1 \%$ probability.

A similar result was found by Grangeiro et al. (2011) who, when evaluating the growth and accumulation of nutrients in coriander and arugula, found an increasing accumulation of dry matter along the days after sowing. According to the same authors, this response is common in leafy vegetables, which usually present initially a slow phase of accumulation of dry mass, intensifying at the end of the cycle. So, this growth behavior in height and diameter of the stem is expected, because as the plants grow, these two variables follow the same pattern.

The variables root length and productivity were adjusted to increasing linear equations, with an increase of 0.21 $\mathrm{cm}$ (Figure 2) and $0.56 \mathrm{~kg} \mathrm{~m}^{2}$ (Figure 3), respectively, along the DAP. When comparing the minimum point (7.14 and 6.41) found in season 28 DAP with the maximum point observed in season 49 DAP (11.34 and 18.03), there was an increase of $37.03 \%$ for the root length and $64.44 \%$ for productivity. 


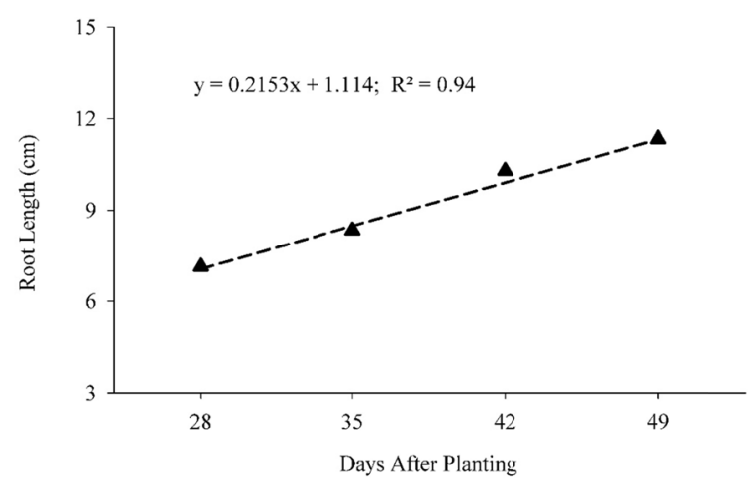

Figure 2. Root length of coriander plants evaluated at different times after sowing Note. ${ }^{* *}$ Significance at $1 \%$ probability.

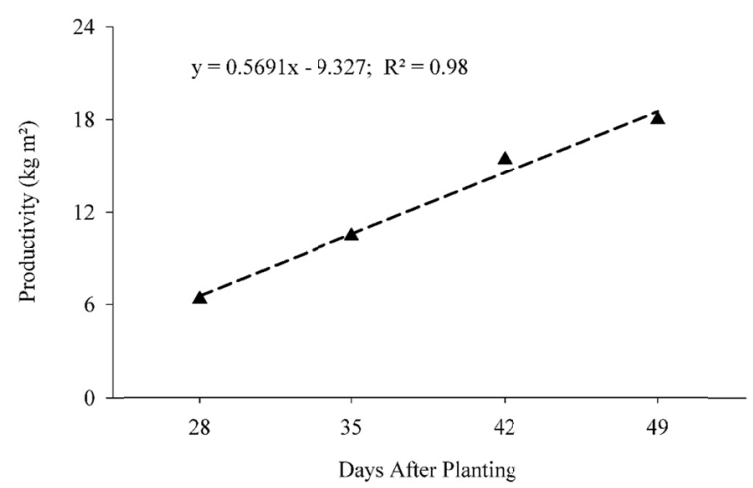

Figure 3. Productivity of coriander plants evaluated at different times after sowing

Note. ${ }^{* *}$ Significance at $1 \%$ probability.

For the variable root length, similar response was found by Costa et al. (2017), that working with vegetative propagation of Lippia alba in different substrates, verified that the root length was higher when cultivated in the substrate with soil and cattle manure and this influenced in a greater number of shoots throughout the epochs of evaluation.

With regard to the increase of coriander productivity according to the epochs, this result is probably related to the greater availability of macronutrients, such as nitrogen, phosphorus and potassium, which, with the passing of the evaluation days, became more readily available for the plants. In this perspective, Linhares et al. (2015), working with coriander, verified that the point of maximum productivity was estimated at 46 days after sowing, which yielded a productivity of $6349 \mathrm{~kg} \mathrm{ha}^{-1}$, which represents the moment of greatest nutritional requirement of the crop in relation to the mineralization of the organic material (bovine manure) and consequently the availability of nutrients in the soil.

Regarding the interactions between fertilization and evaluation times, in both the leaf length variable and the leaf number, 5 linear equations were adjusted over the evaluation periods. For the variable length of leaves, in general, for all the fertilizations used, the plants showed increasing responses throughout the evaluation periods (Figure 4), with emphasis on the treatment with cattle manure + earthworm humus + vegetal organic matter (T5 ), which presented a maximum of $7.92 \mathrm{~cm}$ in the evaluation period 4 (49 DAP). When comparing the maximum point in season 4 , with the minimum point of season $4(4.86 \mathrm{~cm})$, observed when the plants were not fertilized (T1), there was an increase of $38.64 \%$ in plants fertilized with $\mathrm{T} 5$ in relation to $\mathrm{T} 1$. 


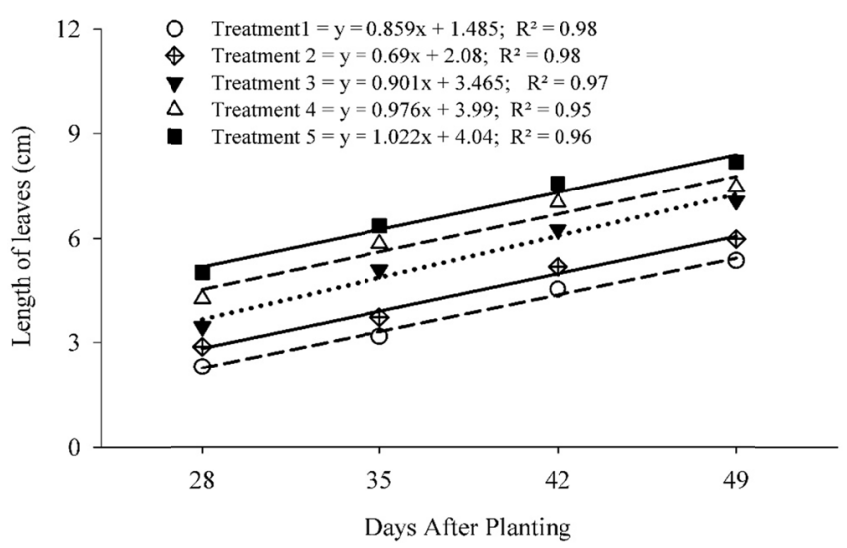

Figure 4. Length of leaves due to the interaction between fertilization and evaluation times in coriander plants Note. $* *$ Significance at $1 \%$ probability; $\mathrm{T} 1=$ no fertilization, $\mathrm{T} 2=$ bovine manure, $\mathrm{T} 3=$ earthworm humus, $\mathrm{T} 4=$ vegetable organic matter and $\mathrm{T} 5=$ bovine manure + earthworm humus + organic vegetable matter.

Melo et al. (2009) when performing the morphological characterization of coriander genotypes, verified that, in general, leaf length was greater than $15 \mathrm{~cm}$. This superiority in leaf length may be related to the climatic conditions of the experiments, as the aforementioned authors performed their experiments in a greenhouse with a screen on the sides and covered with 150 micron clear polyethylene film, while the present experiment was performed under field conditions. As the leaf morphology of plants changes due to solar radiation, the reduction in length may have been affected by high radiation in the experiment period.

For the number of leaves (Figure 5), in general, for all the fertilizations used, the plants showed increasing responses throughout the evaluation periods, especially the treatment with bovine manure (T2), which presented a maximum of 27.2 leaves in evaluation season 4 (49 DAP). When comparing the maximum point in season 4, with the minimum point of season 4 (10.2 leaves), observed when the plants were not fertilized (T1), there was an increase of $62.50 \%$ in the plants fertilized with $\mathrm{T} 2$ in relation to $\mathrm{T} 1$. Although it is not the treatment with the highest concentration of nutrients, possibly the maturation process of the cattle manure, made available these necessary nutrients in a more gradual way, not having great losses by leaching and volatilization which favored the development of the leaves.

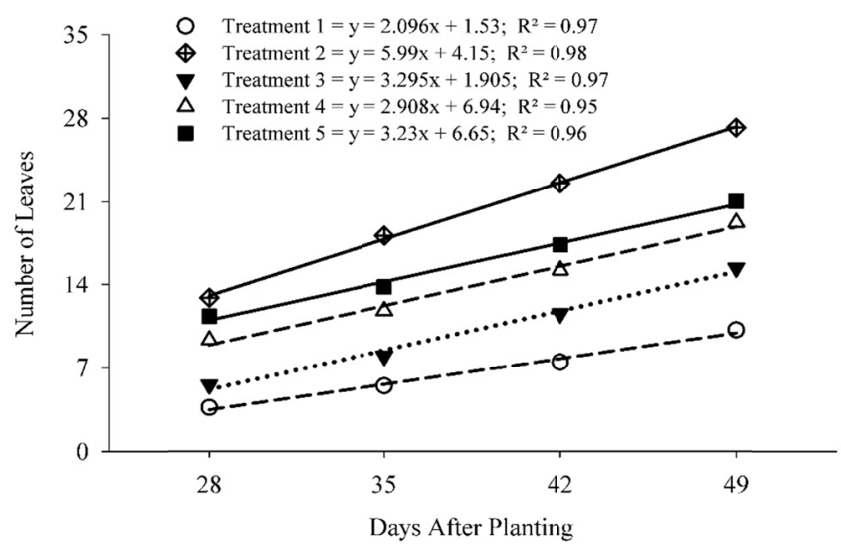

Figure 5. Number of leaves due to the interaction between fertilization and evaluation times in coriander plants

Note. $* *$ Significance at $1 \%$ probability; $\mathrm{T} 1=$ no fertilization, $\mathrm{T} 2=$ bovine manure, $\mathrm{T} 3=$ earthworm humus, $\mathrm{T} 4=$ vegetable organic matter and $\mathrm{T} 5=$ bovine manure + earthworm humus + organic vegetable matter

Linhares et al. (2015), when evaluating the productivity of Coriandrum sativum fertilized with bovine manure at different rates and times of incorporation, obtained results similar to those of the present study, noting a mean increase of one stalk per plant when they were submitted to a dose of $60 \mathrm{t} \mathrm{ha}^{-1}$ in relation to the lowest dose of bovine manure $\left(15 \mathrm{t} \mathrm{ha}^{-1}\right)$ incorporated into the soil, with a mean value of 6.3 plant stems. With regard to the 
time of incorporation, these authors verified that the period of 44 days was the one that promoted a higher average, with the value of 6.6 stems per plant. Therefore, these results demonstrate that coriander when harvested between 40 to 50 days present a high productivity, without however impairing the quality of the final product.

\section{Conclusions}

The most efficient compost for coriander productivity was cattle manure, because it provided better results in most of the analyzed variables. The coriander harvest is indicated at 49 days after sowing, because this season favors a higher agronomic performance of the crop.

\section{References}

Cavalcanti, A. C., \& Lima, J. F. W. F. (2008). Recomendação de adubação para o estado de Pernambuco (2nd ed., p. 199). Recife: IPA.

Costa, R. S., Oliveira, L. K. B., Holanda, I. K. B., Coelho, M. F. B., \& Amorim, A. V. (2017). Vegetative propagation of lemon balm on different substrates. Cientifica, 45(4), 392-397. https://doi.org/10.15361/ 1984-5529.2017v45n4p392-397

Gonet, S. S., Debska, B., Zaujec, A., \& Banach-Szott, M. (2008). Properties of humus of natural forest soil and arable soil. Ekológia (Bratislava), 27(4), 351-366.

Grangeiro, L. C., Lopes, F. C., Negreiros, M. Z., Marrocos, S. T. P., Lucena, R. R. M., \& Oliveira, R. A. (2011). Crescimento e acúmulo de nutrientes em coentro e rúcula. Revista Brasileira de Ciências Agrárias, 6(1), 11-16. https://doi.org/10.5039/agraria.v6i1a634

Linhares, P. C. F., Pereira, M. F. S., Moreira, J. C., Paiva, A. C. C., Assis, J. P., \& Sousa, R. P. (2015). Yield of coriander (Coriandrum sativum L.) fertilized with bovine manure at different rates and time of incorporation in the soil. Revista Brasileira de Plantas Medicinais, 17(3), 462-467. https://oi.org/10.1590/ 1983-084X/13_006

Melo, R. A., Menezes, D., Resende, L. V., Wanderley Júnior L. J. G., Melo, P. C. T., \& Santos, V. F. (2009). Caracterização morfológica de genótipos de coentro. Horticultura Brasileira, 27(3), 371-376. https://doi.org/10.1590/S0102-05362012000300001

Oliveira, A. P., Silva, V. R. F., Santos, C. S., Araújo, J. S., \& Nascimento, J. T. (2002). Produção de coentro cultivado com esterco bovino e adubação mineral. Horticultura Brasileira, 20(3), 477-479. https://doi.org/ 10.1590/S0102-05362002000300016

Rodrigues, E. T., Leal, P. A. M., Costa, E., Paula, T. S., \& Gomes, V. A. (2010). Produção de mudas de tomateiro em diferentes substratos e recipientes em ambiente protegido. Horticultura Brasileira, 28(4), 483-488. https://doi.org/10.1590/S0102-05362010000400018

Rout, G. R., \& Sahoo, S. (2015). Role of iron in plant growth and metabolism. Reviews in Agricultural Science, 3(1), 1-24. https://doi.org/10.7831/ras.3.1

Saldaña, M. I., Gómez-Álvarez, R., Rivera-Cruz, M. D. C., Álvarez-Solís, J. D., Pat-Fernández, J. M., \& Ortiz-García, C. F. (2014). The influence of organic fertilizers on the chemical properties of soil and the production of Alpinia purpurata. Ciencia e investigación agraria, 41(2), 215-224.

Signor, D., \& Cerri, C. E. P. (2013). Nitrous oxide emissions in agricultural soils: A review. Pesquisa Agropecuária Tropical, 43(3), 322-338. https://doi.org/10.1590/S1983-40632013000300014

Silva, E. M., Vieira, E. T. V., Tashima, L. C. N., \& Guilherme, D. O. (2017). A sustainability rereading of agrarian production systems. Interações, 18(4), 43-54. https://doi.org/10.20435/inter.v18i4.1527

Tavella, L. B., Galvão, R. O., Ferreira, R. L. F., Araújo Neto, S. E., \& Negreiros, J. R. S. (2010). Organic faming of coriander in no-tillage system fertilized with compost using dead and living mulching. Revista Ciência Agronômica, 41(4), 614-618. https://doi.org/10.1590/S1806-66902010000400014

Trivelin, P. C. O., Franco, H. C. J., Otto, R., Ferreira, D. A., Vitti, A. C., Fortes, C., ... Cantarella, H. (2013). Impact of sugarcane trash on fertilizer requirements for São Paulo, Brazil. Scientia Agricola, 70(5), $345-352$. https://doi.org/10.1590/S0103-90162013000500009

Wolka, K., \& Melaku, B. (2015). Exploring selected plant nutrient in compost prepared from food waste and cattle manure and its effect on soil properties and maize yield at Wondo Genet, Ethiopia. Environmental Systems Research, 4(1), 1-9. https://doi.org/10.1186/s40068-015-0035-0 
Woolpert, M. (2015). The greatest challenge facing agriculture over the next 5 years. The University of Vermont. USDA.

Zandonadi, D. B., Santos, M. P., Busato, J. G., Peres, L. E. P., \& Façanha, A. R. (2013). Plant physiology as affected by humified organic matter. Theoretical and Experimental Plant Physiology, 25(1), 13-25. https://doi.org/10.1590/S2197-00252013000100003

Zen, H. D., \& Brandão, J. B. (2018). Analysis of the production and marketing of organic vegetables in the state of New York: A case study. Revista Produção e Desenvolvimento, 4(2), 1-20. https://doi.org/10.32358/rpd. 2018.v4.295

\section{Copyrights}

Copyright for this article is retained by the author(s), with first publication rights granted to the journal.

This is an open-access article distributed under the terms and conditions of the Creative Commons Attribution license (http://creativecommons.org/licenses/by/4.0/). 